\title{
PENYUSUNAN DAN ANALISIS TES KINERJA (PERFORMANCE TEST) PADA KOMPETENSI PRAKTIK MEMASANG SISTEM PENERANGAN DAN WIRING KELISTRIKAN DI SMK
}

\author{
Hegar A. Multin', Wahid Munawar², Ridwan A. M. Noor ${ }^{3}$ \\ Universitas Pendidikan Indonesia \\ Jl. Dr. Setiabudi No. 229 Bandung 40154 \\ hegaradhiko@gmail.com
}

\begin{abstract}
ABSTRAK
Penelitian ini bertujuan untuk menyusun tes kinerja dan analisis tes kinerja pada kompetensi praktik memasang sistem penerangan dan wiring kelistrikan di SMK Otomotif. Metode penelitian yang digunakan adalah metode deskriptif. Teknik pengumpulan data analisis tes kinerja. Tes yang dikembangkan yaitu terdiri dari rubrik dan pedoman penilaian. Hasil penelitian tes kinerja berupa uji validitas isi, uji keterbacaan dan uji konstruksi. Konten tes kinerja dilakukan dengan expert judgment. Analisis validitas isi menggunakan rumus CVR dan CVI didapatkan hasil yang valid. Hasil uji tingkat keterbacaan memiliki nilai tinggi setelah dilakukan perbaikan, sehingga instrumen dapat digunakan oleh siapa saja. Hasil uji konstruksi dinyatakan dalam nilai tinggi, artinya terstruktur untuk digunakan. Kesimpulan diperoleh bahwa proses tahapan-tahapan pembuatan instrument tes kinerja dan penyusunan pembuatan instrument tes kinerja yang melalui tahapan demi tahapan hingga menjadi valid dengan pengesahan ahli.
\end{abstract}

Kata kunci: tes kinerja, sistem penerangan, wiring diagram.

\section{PENDAHULUAN}

Pendidikan merupakan faktor yang begitu penting bagi kehidupan suatu bangsa. Melalui pendidikan manusia dapat meningkatkan dan mengembangkan peradaban ilmu pengetahuan dan rekayasa teknologi yang sangat berguna bagi kehidupan manusia. Pendidikan dapat didefinisikan sebagai suatu usaha terencana untuk menyiapkan peserta didik melalui kegiatan bimbingan, pengajaran dan latihan bagi perannya di masa yang akan datang. Kurikulum adalah seperangkat rencana dan pengaturan mengenai tujuan, isi, dan bahan pelajaran serta cara yang digunakan sebagai pedoman penyelenggaraan kegiatan pembelajaran, untuk mencapai tujuan pendidikan tertentu. Ada dua dimensi kurikulum, yang pertama adalah rencana dan pengaturan mengenai tujuan, isi, dan bahan pelajaran, sedangkan yang kedua adalah cara yang digunakan untuk kegiatan pembelajaran.

Dunia industri ini sangat memerlukan keterampilan dalam bidangnya masing-masing. Salah satu cara untuk meningkatkan potensi keterampilan yang dibutuhkan oleh pihak industri

\footnotetext{
${ }^{1}$ Mahasiswa Departemen Pendidikan Teknik Mesin FPTK UPI

2 Dosen Departemen Pendidikan Teknik Mesin FPTK UPI

${ }^{3}$ Dosen Departemen Pendidikan Teknik Mesin FPTK UPI
} 
ini rata-rata merekrut para lulusan Sekolah Menengah Kejuruan (SMK). Lulusan SMK ini memiliki keterampilan yang lebih dibandingkan sekolah sederajatnya. SMK merupakan suatu lembaga pendidikan formal yang kelulusannya dipersiapkan untuk memasuki dunia kerja. Lulusan SMK dituntut agar menjadi manusia yang produktif, yang mampu bekerja mandiri, mampu memilih karier, ulet, gigih dalam berkompetensi, dan bertanggung jawab dalam menjalankan tugas dan kewajibannya. SMK dirancang untuk menyiapkan lulusan yang siap memasuki dunia kerja, dan mampu mengembangkan sikap profesional di bidang kejuruan.

Berkaitan dengan usaha untuk meningkatkan mutu pendidikan SMK dibutuhkan tenaga pendidik yang terampil di bidangnya, dalam hal ini guru. Guru harus mampu mengolah dan menerapkan ilmu pengetahuan dalam bidang teknologi dan industri bagi siswanya. Kompetensi tamatan termasuk ke dalam standar isi dan kompetensi lulusan merupakan suatu kemampuan yang mencakup terhadap sikap, pengetahuan, dan keterampilan yang sesuai dengan standar nasional. Untuk menghasilkan kompetensi lulusan yang mumpuni, kompetensi tersebut harus sesuai dengan standar nasional yang telah ditetapkan. Faktor yang mendukung terhadap kualitas dari kompetensi lulusan salah satunya adalah kompetensi mata pelajaran.

Kompetensi mata pelajaran merupakan salah satu faktor yang berperan terhadap kualitas dari kompetensi lulusan. Kompetensi lulusan yang baik adalah yang memenuhi semua kompetensi pada setiap mata pelajaran. Setiap siswa SMK dituntut untuk memenuhi semua kompetensi yang ada, Sehingga mereka nantinya akan menjadi lulusan yang memiliki kompetensi yang baik dan mereka siap bersaing di dunia kerja. Salah satu program keahlian di SMK yang menuntut semua siswanya memenuhi seluruh kompetensi yang ada adalah program keahlian otomotif.

Tes adalah seperangkat pertanyaan yang memiliki jawaban benar atau salah (Muslich, 2011). Esensi tes adalah prosedur yang spesifik dan sistematis, untuk mengukur tingkah laku seseorang atau suatu kumpulan, yang bersifat objektif mengenai tingkah laku seseorang, sehingga tingkah laku tersebut dapat digambarkan dengan bantuan angka, skala, atau dengan sistem kategori (Ratnawulan dan Rusdiana, 2015). Tes adalah suatu alat pengukur yang spesifik dan sistematis, digunakan untuk memperoleh informasi secara objektif, dan terhadap nilai.

Mengukur adalah membandingkan sesuatu dengan satu ukuran, pengukuran bersifat kuantitatif (Arikunto, 2015). Pengukuran adalah kegiatan yang dilakukan untuk mengukur sesuatu, dimana mengukur pada hakekatnya adalah membandingkan sesuatu dengan atau atas 
dasar ukuran tertentu. (Sudijono, 2001). Pengukuran pada dasarnya merupakan kegiatan penentuan angka bagi suatu objek secara sistematik, untuk menggambarkan karakteristik suatu objek (Linn and Norman, 1995). Penulis menyimpulkan pengertian pengukuran adalah membandingkan suatu data dari objek tertentu menggunakan alat ukur yang sistematis.

Secara singkat evaluasi didefinisikan sebagai proses mengumpulkan informasi untuk mengetahui pencapaian belajar kelas atau kelompok (Mardapi, 2008). Evaluasi berasal dari kata evaluation yang berarti menilai, tetapi dilakukan dengan mengukur terlebih dahulu (Arikunto, 2015). Evaluasi merupakan kegiatan identifikasi program yang telah dilaksanakan, untuk melihat tingkat efisiensi pelaksanaan program (Ratnawulan dan Rusdiana, 2015). Evaluasi adalah proses mengumpulkan informasi untuk mengidentifikasi kegiatan yang telah dilaksanakan seberapa tingkat efisiensi pelaksanaannya, dengan menggunakan alat ukur.

Penilaian kinerja adalah suatu penilaian yang meminta peserta didik untuk melakukan suatu tugas pada situasi yang sesungguhnya yang mengaplikasikan pengetahuan dan keterampilan yang dibutuhkan (Majid dan Firdaus, 2014). Penilaian kinerja (performance assessment) adalah suatu penilaian yang meminta peserta didik untuk mendemonstrasikan dan kriteria yang diinginkan (Wahyuni, 2012). Performance assessment adalah penilaian berdasarkan hasil pengamatan penilai terhadap aktivitas peserta didik sebagaimana yang terjadi. Penilaian dilakukan terhadap unjuk kerja, tingkah laku atau interaksi (Riadi, M., 2012).

Penilaian kinerja meminta siswa untuk menunjukkan kemampuan mereka, bukan menghubungkan apa yang telah mereka pelajari melalui tes tradisional (Suskie, 2009). Penilaian kinerja kadang disebut penilaian alternatif, karena sebagai alternatif untuk penilaian tradisional, pilihan ganda dan tes buku biru. Penilaian kinerja meminta siswa untuk melakukan tugas-tugas kehidupan nyata. Seperti menganalisis studi kasus dengan data bona-fide, melakukan eksperimen laboratorium realistis, atau menyelesaikan magang disebut penilaian otentik. Penilaian kinerja semakin populer karena menggabungkan pembelajaran dan penilaian. Siswa belajar ketika mereka bekerja pada penilaian kinerja, seperti periode pengujian tradisional di mana mereka sering belajar apapun. Penilaian otentik memiliki keuntungan tambahan memberikan situasi belajar siswa yang realistis, di mana mereka memecahkan masalah berantakan di dunia nyata, dengan banyak jawaban diterima, bukan masalah palsu yang hanya ada satu jawaban yang benar. 
Penilaian kinerja adalah suatu penilaian yang menuntut peserta didik untuk mendemonstrasikan life-skill, berupa aspek pembelajaran kinerja produk. Penilaian kinerja cocok untuk menilai praktik, sehingga dikenal sebagai tes praktik/kinerja. Penilaian kinerja pada hal ini yaitu, penilaian kinerja pada kompetensi praktik memasang sistem penerangan dan wiring kelistrikan praktik memasang sistem penerangan dan wiring kelistrikan di SMK.

Karakteristik umum penilaian kinerja sebagai berikut: 1) multikriteria kinerja siswa harus menggunakan penilaian yang memiliki lebih dari satu kriteria; 2) standar kualitas yang spesifik, masing-masing kriteria kinerja siswa dapat dinilai secara jelas dan eksplisit dalam memajukan evaluasi kualitas kinerja siswa; dan 3) adanya judgement penilaian (Abidin, 2016). Penilaian kinerja membutuhkan penilaian yang bersifat manusiawi untuk menilai bagaimana kinerja siswa dapat diterima secara nyata (real), bukan menilai dengan menggunakan angka pada komputer atau mesin (seperti pada tes baku).

Penilaian kinerja terdiri dari 2 bagian, yaitu tugas dan rubrik penskoran (Majid dan Firdaus, 2014). Tugas itu dapat menghasilkan satu produk, kinerja, atau uraian jawaban dari satu pertanyaan yang menuntut peserta didik menerapkan keterampilan berpikir. Rubrik penskoran ialah skema penilaian deskriptif yang digunakan sebagai patokan dalam menganalisis produk maupun proses usaha dan keberhasilan peserta didik. Rubrik dapat dikatakan sebagai format spesifik dari suatu instrumen yang digunakan untuk mengevaluasi berbagai produk atau kegiatan. Ada 2 jenis rubrik, yaitu: rubrik holistik, penskoran dilakukan terhadap proses keseluruhan atau kesatuan produk tanpa menilai bagian komponen secara terpisah dan rubrik analitik, penskoran mula-mula dilakukan atas bagian-bagian individual produk atau penampilan secara terpisah, kemudian dijumlahkan skor individual itu untuk memperoleh skor total.

Langkah-langkah pengembangan tes, adalah menyusun spesifikasi tes/kisi-kisi tes, menulis instrumen/soal tes, menelaah butir tes, uji coba instrumen tes, analisis instrumen tes, merevisi/penyempurnaan instrumen tes, melaksanakan tes, dan menafsirkan hasil tes (Muslich, 2011).

\section{METODE PENELITIAN}

Metode penelitian yang digunakan adalah penelitian deskriptif. Hasil penelitian ditekankan pada pemberian gambaran secara objektif, tentang keadaan yang sebenarnya dari objek yang diteliti. Metode penelitian deskriptif digunakan untuk mendeskripsikan, 
menginterpretasikan sesuatu peristiwa, misalnya kondisi atau hubungan yang ada, pendapat yang berkembang, dengan menggunakan prosedur ilmiah untuk menjawab masalah secara aktual. Peneliti mendeskripsikan sebuah peristiwa yang terdapat pada penyusunan dan analisis tes kinerja pada kompetensi kompetensi praktik memasang sistem penerangan dan wiring.

Teknik pengumpulan data pada penelitian ini menggunakan penyusunan dan analisis tes kinerja (performance test). Teknik yang digunakan dalam mengumpulkan data adalah dengan melakukan penyusunan dan analisis tes kinerja. Tes yang dikembangkan yaitu tes untuk mengukur kompetensi peserta didik pada kompetensi praktik memasang sistem penerangan dan wiring kelistrikan, yang terdiri dari rubrik dan pedoman penilaian.

Analisis data merupakan sebagai tahapan akhir sebelum menarik kesimpulan yang merinci usaha secara formal. Data yang diperoleh dari penyusunan tes kinerja pada kompetnsi dasar membuat (fabrikasi) komponen fiberglas/komposit. Analisis data yang dilakukan adalah hasil pengujian validasi isi, data hasil uji keterbacaan dan konstruksi. Analisis hasil pengujian validasi instrument penelitian dilakukan menggunakan Content Validity Rasio (CVR) dan Content Validity Index (CVI).

Produk yang dihasilkan dari peneleitian ini adalah langkah kerja pada kondisi nyata dengan instrumen yang belum tervalidasi oleh ahli dan pedoman penilaian yang belum tervalidasi. Penyusunan butir soal tes kinerja disusun menjadi beberapa sub tes yaitu persiapan kerja operator, persiapan alat dan bahan, proses kerja. Aspek yang terdapat dalam butir soal proses kerja yaitu menggambar wiring diagram lampu kepala, merangkai wiring lampu kepala, menggambar wiring diagram lampu tanda berhenti, merangkai wiring kelistrikan lampu tanda berhenti, menggambar wiring diagram lampu tanda mundur, merangkai wiring lampu tanda mundur, menggambar wiring diagram lampu tanda belok dan lampu hazard, dan merangkai wiring lampu tanda belok dan lampu hazard.

\section{HASIL PENELITIAN}

Pengujian validitas instrumen penelitian dilakukan pada lembar penilaian tes praktik memasang sistem penerangan dan wiring kelistrikan. Hasil pengujian dianalisis menggunakan Content Validity Ratio (CVR) dan Content Validity Index (CVI). Analisis hasil pengujian validitas penilaian tes praktik memasang sistem penerangan dan wiring kelistrikan selain menggunakan CVR, juga menggunakan CVI. 
Validasi bertujuan untuk mengukur dan mengetahui sejauh mana ketepatan dan keterbacaannya suatu alat ukur dalam melakukan pengukurnya. Adapun dalam penelitian ini validitas yang digunakan adalah validitas isi (content validity) (Lawshe, 1975). Setelah penyusunan instrumen tes kinerja, maka instrumen tes tersebut dan perangkat yang telah dibuat diajukan kepada tim ahli (judgement expert) untuk dianalisis secara teoritik dan mengetahui validitas pada instrumen tes yang telah disusun. Validasi isi dalam penelitian ini dilakukan oleh tim ahli yang terdiri dari 5 orang yaitu 3 orang dari pihak industri otomotif, 1 orang dari pihak sekolah, dan 1 orang dari tim dosen bersangkutan. Uji validasi oleh 5 ahli dan analisis menggunakan rumus CVR dan CVI, ditemukan kesalahan penulis dalam menggunakan katakata agar lebih konsisten dalam menggunakan bahasa. Sehingga penulis harus memperbaiki bahasa yang seharusnya agar konsisten dalam menyebutkan nama komponen.

Selain uji validasi, instrumen juga dilakukan uji keterbacaan, untuk memperoleh data tingkat keterbacaan dalam persen. Hasil uji keterbacaan butir tes terdapat 10 butir tes yang memiliki tingkat keterbacaan tinggi namun harus diperbaiki penggunaan nama komponen agar konstan menggunakan satu bahasa. Persentase keterbacaan butir diperoleh $100 \%$ baik. Akan tetapi, ada beberapa koreksi saat melakukan judgement pada ahli dari pihak industri tentang penggunaan bahasa komponen dalam lembar instrument yang penulis lakukan. Berdasarkan saran dan masukkan dari validator terhadap aspek keterbacaan instrumen penilaian kinerja yang dikembangkan, kemudian dilakukan revisi terhadap lembar instrumen kinerja praktikum tersebut, sehingga dihasilkan produk baru yang lebih valid dan disebut sebagai draf (produk)

Aspek konstruksi untuk ruang lingkup/kriteria penilaian pada instrumen penilaian kinerja praktikum yang disusun perlu diperbaiki. Hal tersebut dilakukan karena belum sesuai dengan konsistensinya bahasa yang digunakan untuk lembar instrument tersebut. Menurut validator I, kriteria pemilihan rangkaian harus di sesuaikan karna belum memiliki kejelasan yang harus di lakukan oleh peserta test. Hal tersebut dikemukakan karena nama komponen tidak di sebutkan pada stiap rangkaian. Menurut validator II, ada beberapa kriteria bahasa yang harus di gunakan agar lebih konsisten yaitu: 1) kata accu/baterai ambilah salah satu apabila menggunakan bahasa Indonesia semua menggunakan bahasa Indonesia apabila menggunakan bahasa asing gunakan bahasa asing, 2) pada aspek gambar komponen berilah nama agar peserta test dapat memahami simbol-simbol yang sedang ia kerjakan. Menurut validator III gambar pada instrumen kurang jelas, sehingga membingungkan pengguna awam. Seharusnya gambar diberi nama komponen 
agar peserta dapat membacanya dengan jelas. Hal ini karena pengguna instrumen kinerja praktikum tersebut dan pemberi skor adalah orang yang akhli dalam bidang otomotif di industri. Akan tetapi yang mengetahui keadaan sebenarnya saat dilapangan adalah guru praktik dalam mata pelajaran yang bersangkutan dan guru yang lebih tau kemampuan pesertanya untuk mencerna sebuah soal. Menurut validator IV bahasa dalam nama komponen harus konsisten agar pembaca instrument tersebut tidak merasa kebingungan. Menurut validator V instrumen terasa telah cocok dengan yang dibutuhkan pihak sekolah dikarenakan belum adanya penilaian suatu test praktik yang baku untuk digunakan di sekolah. Validator mengharapkan untuk mau membantu pihak sekolah agar dapat menggunakan hal serupa yang sedang penulis lakukan untuk mata pelajaran yang lain. Hasil uji konstruksi awal ditemukan 7 butir dengan konstruksi baik dan 3 butir soal harus diperbaiki konstruksinya. Persentase aspek konstruksi instrumen diperoleh $60 \%$.

Berdasarkan saran dan masukkan dari validator terhadap aspek konstruksi, instrumen test praktikum yang disusun, kemudian dilakukan revisi terhadap instrumen test praktikum tersebut, sehingga dihasilkan produk baru yang lebih valid dan disebut sebagai draf (produk). Setelah dilakukan telaah sebanyak dua kali, didapatkan data sebagai berikut: uji konstruksi 1 rata-rata $75 \%$, uji konstruksi 2 diperoleh $80 \%$ dan rata-rata diperoleh 77,5\%. Setelah instrumen dilakukan telaah, validasi isi, uji keterbacaan dan uji konstruksi, kemudian dilakukan revisi berdasarkan saran para validator, maka produk instrumen tes kinerja yang telah terkalibrasi, siap untuk digunakan.

\section{PEMBAHASAN}

Belum adanya instrument penilaian yang sesuai untuk membuat siswa mengetahui sudah sampai sejauh mana keberhasilan praktik merangkai wiring klistrikan yang mereka lakukan karena tidak ada standard yang jelas. Sehingga penulis membuat sebuah tes kinerja kompetensi praktik memasang sistem penerangan dan wiring kelistrikan di SMK Bakti Ilham agar instruktur atau guru dan siswa mengetahui bagaimana teknik yang benar, yang efektif dan efisien lengkap dengan penilaian untuk pelaksanaannya.

Validitas instrumen tes kinerja ini telah divalidasi atau divalidkan oleh 5 (lima) orang yang ahli bidang otomotif khususnya dalam bidang kelistrikan body otomotif. Berdasarkan data hasil uji validitas, nilai CVR dan CVI meningkat setelah dilakukan judgment dan perbaikan sebanyak 
2 kali. Nilai akhir CVInya adalah 1 dan termasuk dalam kategori valid. Hal ini menunjukan instrument tes kinerja dan pedoman penilaian, pada kompetensi membuat (fabrikasi) komponen fiberglas/bahan komposit yang dibuat valid.

Hasil uji keterbacaan instrumen dapat terlihat bahwa, instrumen kasar memiliki tingkat keterbacaan yang rendah, karena masih banyak sekali bahasa dan susunan kata atau kosa kata yang konsisten. Banyak sekali masukan dari validator, sehingga perlu untuk diperbaiki. Setelah instrumen selesai diperbaiki nilai persentase daya keterbacaan naik menjadi 77,5\%. Hasil tersebut sudah cukup baik karena termasuk dalam kategori tinggi. Akan tetapi, masih harus dilakukan perbaikan, agar tingkat keterbacaanya menjadi sangat tinggi. Hal ini menunjukan, tampilan dari instrumen tes kinerja pada praktik memasang sistem penerangan dan wiring kelistrikan, yang dibuat mudah dipraktikan dan dapat digunakan oleh siapa saja di SMK.

Hasil uji konstruksi instrumen tes kinerja awal, aspek konstruksi termasuk dalam kategori tinggi, namun ada beberapa masukan yang sangat penting dari validator, sehingga tampilan instrumen tes kinerja menjadi lebih baik dan menarik. Setelah dilakukan perbaikan pada aspek yang disarankan, aspek konstruksi menjadi sangat tinggi. Hal ini menunjukkan, tampilan dari instrumen tes kinerja pada kompetensi praktik memasang sistem penerangan dan wiring kelistrikan, yang dibuat menarik dan terstruktur. Tes kinerja kompetensi praktik memasang sistem penerangan dan wiring kelistrikan ini valid dan terkalibrasi, sehingga dapat digunakan sebagai standar tes pengukuran kompetensi praktik memasang sistem penerangan dan wiring kelistrikan di SMK.

\section{KESIMPULAN}

Penyusunan kisi-kisi, langkah kerja, butir soal dan pedoman penilaian tes kinerja dapat dipergunakan sebagai bahan kajian, proses berlatih, pembelajaran, dan mengadakan penilaian, untuk kemudian mengevaluasi hasil pembelajaran. Produk instrumen tes kinerja dan pedoman penilaian yang terkalibrasi dan terstruktur dapat digunakan contoh untuk penilaian kinerja praktik di SMK.

\section{REFERENSI}

Abidin, Y. (2016). Desain Sistem Pembelajaran dalam Konteks Kurikulum 2013. Bandung: PT Refika Aditama. 
Arikunto, S. (2015). Dasar-Dasar Evaluasi Pendidikan. Jakarta: PT. Bumi Aksara.

Lawshe, C. H. (1975). A Quantitative Approach to Content Validity. Personnel Psychology, (28), 563-575.

Linn, R. L. and Norman E. G. (1995). Measurement and Assessment in Teaching. New Jersey: A Simon \& Schuster Company.

Majid, A. dan Firdaus A. (2014). Penilaian autentic proses dan hasil belajar. Bandung: Interes Media.

Mardapi, D. (2008). Teknik Penyusunan Instrumen Tes dan Non Tes. Yogyakarta: Nuha Medika.

Muslich, M. (2011). Autentic Assesment: Penilaian Berasis Kelas dan Kompetensi. Bandung: PT. Refika Aditama.

Ratnawulan E. dan Rusdiana H.A. (2015). Evaluasi Pembelajaran. Bandung: CV. Pustaka Setia.

Riadi, M. (2012). Penilaian kinerja (performace assesment). [Online]. Diakses dari: http://www.kajianpustaka.com/2012/11/penilaian-kinerja performace-assesment.html.

Suskie, L. (2009). Assessing Student Learning a Common Sense Guide. San Francisco: JosseyBass.

Wahyuni, S. (2012). Assesmen Pembelajaran Bahasa. Bandung: Refika Aditama. 